\title{
Stock recovery, spawning period and spawning area expansion of the twaite shad Alosa fallax in the Elbe estuary, southern North Sea
}

\author{
Victoria Magath*, Ralf Thiel \\ University of Hamburg, Biocentre Grindel and Zoological Museum, 20146 Hamburg, Germany
}

\begin{abstract}
After a serious decline in the past, some twaite shad Alosa fallax populations have significantly recovered during the last decade. Although increasing numbers of the species occur in areas of the southern North Sea, detailed quantitative analyses have not been published on spawning stocks of specific North Sea estuaries. In this study, the development of the twaite shad spawning stock of the Elbe estuary, its spawning period and spawning area were determined using abundance data, gonad maturity information and the gonadosomatic index. Abundances were compared between the periods 1992-1993 and 2009-2010, and environmental parameters were included in the analysis. Abundances have increased significantly in recent years, which could be a result of more favourable climatic conditions. The spawning period, from at least early May until mid-June, has not changed since the early 1960s; however, an abundance increase in April suggested a compact immigration of spawners. The spawning area was located in the middle and upper estuary, but has been extending downstream since the 1990s and is now found in freshwater as well as in areas of low salinity $(0.5 \pm 0.1)$. This might be caused by significantly lower salinities in the middle and upper estuary in comparison with the conditions in the 1990s. The current vulnerability status of twaite shad in the German North Sea region should be re-evaluated; however, stocks should be monitored continuously to ensure maintenance of the population.
\end{abstract}

KEY WORDS: Twaite shad · Anadromous fish · Population recovery $\cdot$ Elbe estuary $\cdot$ Spawning period $\cdot$ Spawning area

\section{INTRODUCTION}

Historically, the twaite shad Alosa fallax (Lacépède, 1803) was a widely distributed species in Europe, occurring in the Baltic and North Seas (Stelzenmüller et al. 2004, Thiel et al. 2008), the Northeast Atlantic (Taverny \& Elie 2001) and the Mediterranean and Black Seas (Turan \& Basusta 2001, López et al. 2007). However, populations suffered from anthropogenic impacts, in particular water pollution and hydraulic engineering work, including the building of weirs (Aprahamian \& Aprahamian 1990, Aprahamian et al. 2003). Twaite shad declined throughout Europe and even became extinct in some rivers (Bervoets et al. 1990, Sabatié \& Baglinière 2001). For this reason, the twaite shad has been included in a number of European national red lists, e.g. listed as extinct in the Netherlands and Luxembourg (Aprahamian et al. 2003), endangered in Belgium, Denmark and Germany (Fricke et al. 1994, Berg 1998, Aprahamian et al. 2003), and vulnerable in Spain, Portugal, Poland, Ireland and the UK (Aprahamian et al. 2003), and it has also been listed in Annexes II and V of the European Directive on the conservation of natural habitats and of wild fauna and flora (Habitats Directive 92/43/EEC of 21 May 1992) as well as in Annex III of the Bern Convention.

Nowadays, the overall economic importance of twaite shad appears to be low (Aprahamian et al. 2003, Maitland \& Hatton-Ellis 2003), although it is 
commercially fished in countries such as France or Lithuania (Aprahamian et al. 2003, Repečka 2003, Maksimov 2004). In the recent past, improvements in water quality predominantly led to a recovery of some twaite shad spawning populations in the Baltic Sea (Repečka 2003, Maksimov 2004, Thiel et al. 2008) as well as in the Mediterranean (López et al. 2007). There are also earlier observations of increased numbers of twaite shad from surveys performed in coastal and offshore areas of the southern North Sea for the period 1996 to 2004 (Stelzenmüller et al. 2004, Neudecker \& Damm 2005, Thiel \& Backhausen 2006), although no significant increase was observed in the Wadden Sea (Jager et al. 2009). Furthermore, there are indications of an initial stock increase in the Weser estuary (Scholle \& Schuchardt 2012) and the reappearance of twaite shad in the Scheldt (Maes et al. 2005). However, no detailed quantitative analysis on the status of the twaite shad spawning stock in a North Sea estuary has been published recently.

One of the most important spawning stocks of twaite shad in the North Sea region occurs in the Elbe estuary (e.g. Möller \& Dieckwisch 1991), one of the largest estuaries in Europe (Pihl et al. 2002). The current status of this population is unknown. As is true of many estuaries, the Elbe estuary is highly impacted by human activities such as channelisation, industry and fisheries (Thiel 2003, 2009). After a serious decline in the past (Sterner 1918, Kühl 1976), the twaite shad population of the Elbe estuary was found to be relatively stable in the early 1990s (Thiel et al. 1996). However, since then, there has been a further deepening of the navigation channel as well as a reduction of the shallow water regions (Kerner 2007, Thiel 2009). These measures resulted in a reduction of both the specific water surface area and the aeration capacity of the shallow water regions, and therefore caused an impairment of the oxygen situation in the Elbe estuary (FGG Elbe 2007, Kerner 2007). It is not yet known whether these activities affected the twaite shad population.

The protection of twaite shad on its spawning grounds in this heavily impacted estuary is necessary to ensure the long-term maintenance of the population (e.g. Costello et al. 2002). For that purpose, the spawning period as well as the spawning area must be known. Direct observations of spawning events could provide such information (López et al. 2007, López et al. 2011), but this would require extensive surveys on potential spawning grounds (López et al. 2011). In the case of the Elbe estuary in the late 1990s, the spawning area had a longitudinal extent of approximately $25 \mathrm{~km}$ (Thiel et al. 1996, Gerkens \& Thiel 2001), and thus this procedure would not be effective. Sampling of early life stages (eggs, early larvae) is another possible sampling method; however, this would necessitate complex catch methods (Hass 1968). In contrast, adult fish are easier to obtain, and gonad maturity and gonadosomatic index (GSI) of adults could provide information on the spawning period and the spawning area (e.g. Massmann 1952, Maitland \& Lyle 2005, King \& Roche 2008).

As far as it is known from one of the earliest observations in the late 19th century, twaite shad have always spawned in the estuarine part of the Elbe (Ehrenbaum 1894). At that time, from estimations of occurrence data of early life stages, the spawning area extended approximately from river kilometres (rkm) 650 to 680, and the main spawning habitat appeared to be close to the upper border of this area. However, a displacement of the spawning area to rkm 655-705 was identified for the Elbe population in the 1960s (Hass 1968). At the same time, the main spawning habitat was shifted to rkm 670-680, and this habitat persisted in the middle of the 1980s (Möller \& Dieckwisch 1991). Estimates derived from abundances of early and adult life stages indicated an upstream shift of the spawning area to rkm 645660 in the 1990s as a result of reduced water pollution (Thiel et al. 1996, Gerkens \& Thiel 2001). However, the present upstream and downstream extent of the spawning area is not known. Additionally, hardly any data exist on the duration of the spawning period of twaite shad, which could have been affected by climate change in recent decades.

In the present study, the status of the Elbe spawning stock of twaite shad was evaluated. For that purpose, (1) abundance data from 2009 and 2010 of adult twaite shad were compared with prior data from 1992 to 1993 taking water temperature, oxygen concentration and salinity into consideration. Furthermore, gonad maturity and GSI data from 2010 were used in combination with abundances to determine (2) the duration of the spawning period and (3) the present extent of the spawning area in the Elbe estuary.

\section{MATERIALS AND METHODS}

\section{Sampling}

Adult twaite shad Alosa fallax were sampled in the Elbe estuary (Fig. 1A) by research surveys between April and October 2009 as well as between March 
and October 2010. Samples were collected on 6 consecutive days each month. In 2010, additional samples $(\mathrm{N}=43)$ were obtained from the cooling water system of the Brokdorf nuclear power plant to increase the sample size for the analysis of gonad maturity and GSI. These were taken on individual days between March and October. In total, samples were obtained from 12 locations (hereafter referred to as stations) in the estuary. These are close to the city of Cuxhaven (downstream) and the city of Hamburg (upstream) (Fig. 1B). The stations were located in one of 3 subareas - the lower (rkm 680-720), middle (rkm 660-680) or upper estuary (rkm 630-660) which were characterised by different salinities (Arge Elbe 2005). During the research surveys, 4 stow net hauls ( 2 during flood and 2 during ebb) were made at each station with a duration of $\sim 90$ min each. They were conducted using a commercial stow net

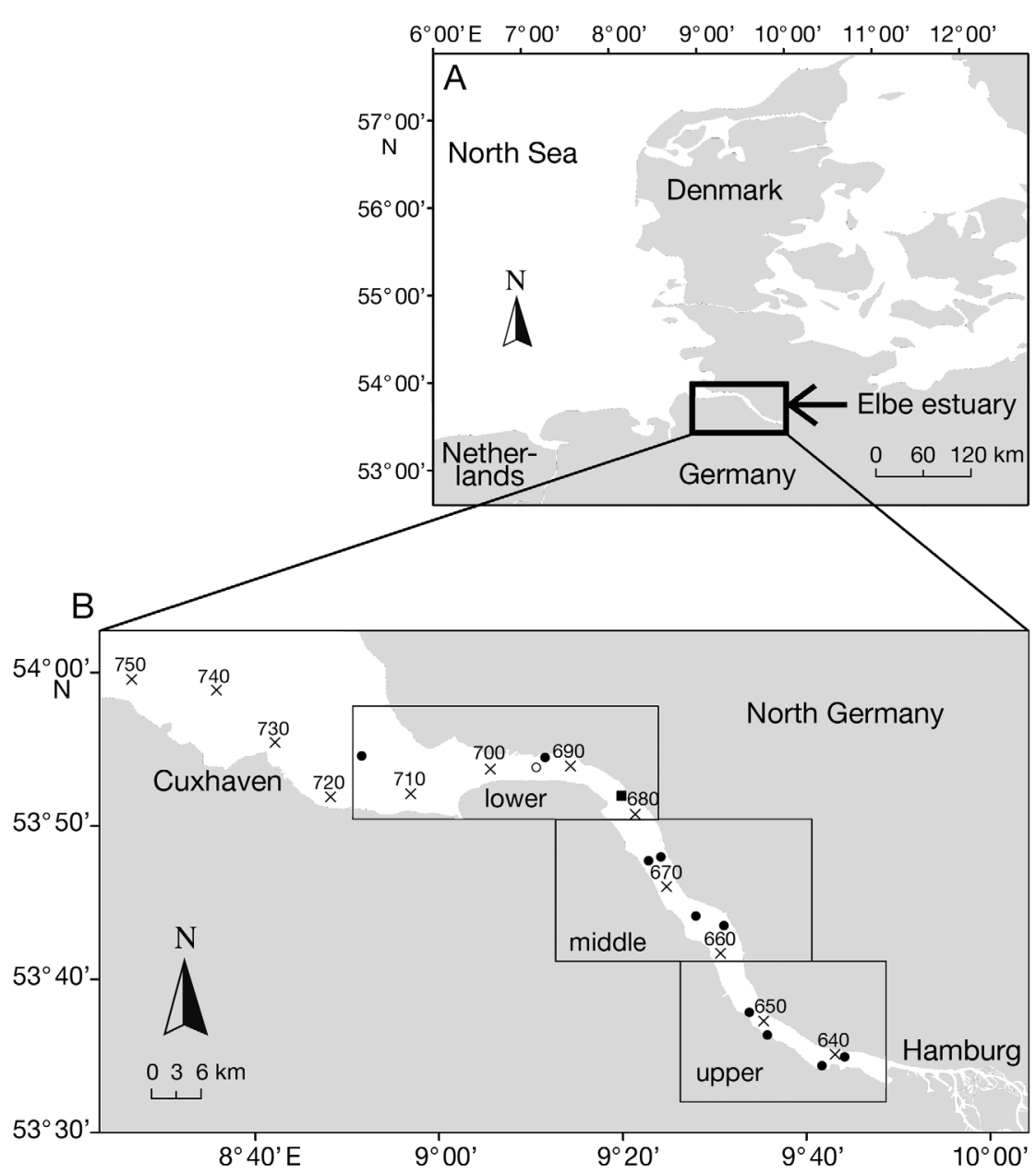

Fig. 1. Location of (A) the Elbe estuary and (B) the study area showing the lower, middle and upper estuary subareas. River $\mathrm{km}(\times)$ and sampling stations from both power plant samplings ( $(\boldsymbol{)})$ and research surveys $(\bullet)$ are illustrated. All but one station from research surveys (o) were also used in 1992 and 1993 vessel with a net opening of $135 \mathrm{~m}^{2}$ (main stream) or $108 \mathrm{~m}^{2}$ (marginal areas) and a mesh size of $8 \mathrm{~mm}$ measured knot to knot in cod end. Three mechanical flowmeters (Hydrobios and General Oceanics) were installed between the upper and lower beam of the net opening (at 1,4 and $7 \mathrm{~m}$ depth) to determine the water volume that passed through the net during fishing. Salinity, water temperature $\left({ }^{\circ} \mathrm{C}\right)$ and oxygen concentration $\left(\mathrm{mg} \mathrm{l}^{-1}\right)$ were measured at the beginning and end of each stow net haul using a portable multi probe U 50 (HORIBA). Both values were first averaged for each haul, and those values were then averaged for each subarea and fishing survey.

Abundances of adult twaite shad in the Elbe estuary between the years 1992 and 1993 were taken from Thiel et al. (1996). Similar to the recent samplings from 2009 and 2010, the data from 1992 and 1993 were obtained by monthly research surveys

(see Thiel et al. 1996). The sampling stations corresponded to the stations used during the years 2009 and 2010 except for one station in the lower estuary, which was exclusively used during research surveys in 2009 and 2010 (Fig. 1B). In 1992 and 1993, 2 hauls (one during flood tide, one during ebb tide) were made per station with a duration of $\sim 240$ min each. The commercial stow net vessel had an opening area of $90 \mathrm{~m}^{2}$ and a mesh size of $8 \mathrm{~mm}$. Mechanical flowmeters were used similarly.

\section{Catch analysis}

After each catch, fish were identified, counted and measured for total length $\left(L_{\mathrm{T}}, 5 \mathrm{~mm}\right.$ below). Twaite shad were further divided into age groups based on their length-frequency distribution to identify all adult individuals of age group $\geq 2$ belonging to the spawning stock. $L_{\mathrm{T}}$ of age group $\geq 2$ depended on the month and year of sampling, but was at least $210 \mathrm{~mm}$. This procedure was previously verified for a part of the population $(\mathrm{N}=$ 223) by scale readings.

Abundances $\left(A_{i}\right.$ ind. per $\left.10^{6} \mathrm{~m}^{3}\right)$ of adult twaite shad were calculated from the number of caught individuals as follows: 


$$
A=\left(N \times 10^{6}\right) /\left(\mathrm{O}_{\text {net }} \times F \times X\right)
$$

where $N$ is the number of individuals per haul, $\mathrm{O}_{\text {net }}$ is the net opening $\left(\mathrm{m}^{2}\right), F$ is the value of the mechanical flowmeters (dimensionless) and $X$ is the multiplication factor used to convert $F$ into a length (m).

In 2010, the total weight ( $W$, to the nearest $1 \mathrm{~g}$ ) of all individuals analysed with regard to their gonad maturity and GSI was measured. Macroscopical gonad maturity was determined (Klinkhardt 1996) and twaite shad were classified into prespawning (Stages 1 to 5), spawning (Stage 6) and postspawning (Stages 7 and 8) individuals. For a subsample of these individuals, gonadal weight $\left(W_{\mathrm{G}}\right)$ was measured to the nearest $0.1 \mathrm{~g}$. The GSI (\%) was calculated as:

$$
\mathrm{GSI}=\left(W_{\mathrm{G}} / W\right) \times 100
$$

An overview of the samples taken in 2009 and 2010 and their origin is given in Table 1.

\section{Data and statistical analyses}

Twaite shad abundances for the years 1992, 1993, 2009 and 2010 were compared for the months April to June. From April to September 2010, abundances were divided by each month and subarea. Subsequently, these were compared with the spawning period and the location of the spawning area determined from gonad maturity and GSI.

The spawning period was determined using both gonad maturity and GSI data in 2010. For gonad maturity, the spawning period was defined as the period in which spawning individuals occurred in the Elbe estuary. The spawning period was considered to be finished once all individuals of one sampling date had become postspawning individuals. For GSI data, the major spawning period was defined as the time between 2 sampling dates where a clear drop in the average GSI was observed. This was determined for males and females separately.
The spawning area was identified using gonad maturity in 2010. The spawning area was considered to be that part of the estuary where the number of spawning individuals was significantly higher than in other subareas.

Water temperature, oxygen concentration and salinity for April to June 2009 and 2010 were compared with earlier findings from 1992 to 1993 (Thiel et al. 1995, Thiel \& Potter 2001). As water temperature does not differ significantly between the subareas of the Elbe estuary (Thiel \& Potter 2001), it was analysed by month only. Oxygen concentrations measured were checked for critical periods (i.e. periods when concentrations are $<4 \mathrm{mg} \mathrm{l}^{-1}$; see Möller \& Scholz 1991). Salinity was analysed by month and subarea.

All statistical analyses were performed using $\mathrm{R}$ 2.11.1 (R Development Core Team 2011). The chisquared test was used to test for differences in gonad maturity, whereas the Fisher's exact test was conducted in case of $2 \times 2$ matrices or as a post hoc test. The Kruskal-Wallis test, followed by a MannWhitney $U$-test, was carried out to test for differences in GSI and abundances between sampling dates. For all post hoc tests, Bonferroni correction was used. Whenever test statistics of several tests are represented together for ease of reading, ranges are given. Mean values are given along with standard deviations (SD), whereas median values are provided with ranges.

\section{RESULTS}

\section{Abundances}

In the 'Results' section, abundance data are given as number of ind. per $10^{6} \mathrm{~m}^{3}$. Units are omitted for ease of reading. From April to June 1992 and 1993, median abundances of the twaite shad spawning stock were 0.9 (range: 0-244.9) and 0 (range: 0-154.7),

Table 1. Alosa fallax. Samples of adult twaite shad for the calculation of abundance, gonad maturity and gonadosomatic index (GSI). Sample sizes (N) are indicated; means are \pm SD. Detailed information on data origin is given in 'Materials and methods: Sampling'

\begin{tabular}{|lcccccl}
\hline Analysis & Year & N & Sex & Total length $(\mathrm{mm})$ & Mass $(\mathrm{g})$ & Origin \\
\hline Abundance & 2009 & 3086 & Male and & $352 \pm 49$ & - & Research surveys \\
& 2010 & 4298 & female & $370 \pm 36$ & - & \\
Gonad maturity & 2010 & 455 & Male & $354 \pm 23$ & $354 \pm 92$ & Research surveys, power plant \\
& & 187 & Female & $404 \pm 27$ & $574 \pm 143$ & \\
GSI & 2010 & 250 & Male & $359 \pm 23$ & $367 \pm 91$ & Research surveys, power plant \\
& & 130 & Female & $409 \pm 28$ & $598 \pm 160$ & \\
\hline
\end{tabular}


respectively. In 2009, median abundances of 27.3 (range: 0-2345.7) occurred, while in 2010 median abundances were 11.9 (range: 0-1412.9). Abundances differed significantly between the 2 periods under study for the combined months April to June (Kruskal-Wallis test, $H=39.7, \mathrm{df}=3, \mathrm{p}<0.001, \mathrm{~N}=$ 328; Fig. 2A). In 2009 and 2010, abundances were significantly greater than in 1992 and 1993 (MannWhitney $U$-test, $U=850-1313, \mathrm{df}=1, \mathrm{p}<0.001, \mathrm{~N}=$ 164 for 4 pairwise comparisons). These differences between the decades were most apparent when considering April data only $(H=38.0, \mathrm{df}=3, \mathrm{p}<0.001$, $\mathrm{N}=$ 118; Fig. 2B). In 1992 and 1993, median abundances were 0 (range: 0-13.7) and 0 (range: 0-0.7), respectively. In 2009 and 2010, median April abundances of 27.3 (range: 0-926.5) and 14.6 (range: 0-735.0) occurred, respectively. Abundances were significantly higher in April 2009 and 2010 than in April 1992 and $1993(U=37.5-140.0, \mathrm{df}=1, \mathrm{p}<0.001$, $\mathrm{N}=58$ for 4 pairwise comparisons). In May and June, these differences were less prominent, but abundances in 1992 or 1993 have never been significantly higher than in the 2000s. Furthermore, May abundances of 87.4 (range: 0-2345.7) and 63.4 (range: 0-1412.9) in 2009 and 2010, respectively, were significantly higher than abundances of 7.9 in May 1992 (range: 0-244.9; $U$ $=54.0-68.0, \mathrm{df}=1, \mathrm{p}<0.001, \mathrm{~N}=54$ for 2 pairwise comparisons). In June 1992 and 1993, abundances of 0 (range: 0-3.6) and 0 (range: 0-2.4), respectively, were significantly lower than abundances of 5.2 (range: $0-178.4)$ in June $2009(U=70.0-71.5$, $\mathrm{df}=1, \mathrm{p}<0.01, \mathrm{~N}=52$ for 4 pairwise comparisons).

\section{Spawning period}

In 2010, adult Alosa fallax were present in the Elbe estuary on sampling dates from 6 April until 11 September. Spawning individuals were found from 3 May to 16 June in 2010 (Fig. 3A). The average GSI for males and females differed significantly between the sampling dates (males: $H=148.7, \mathrm{df}=9, \mathrm{p}<0.001, \mathrm{~N}=250$; females: $H=72.7, \mathrm{df}=10, \mathrm{p}<0.001$, $\mathrm{N}=130$ ). Male GSI was maximal on 3 May and decreased clearly afterwards (Fig. 3B); however, a statistical

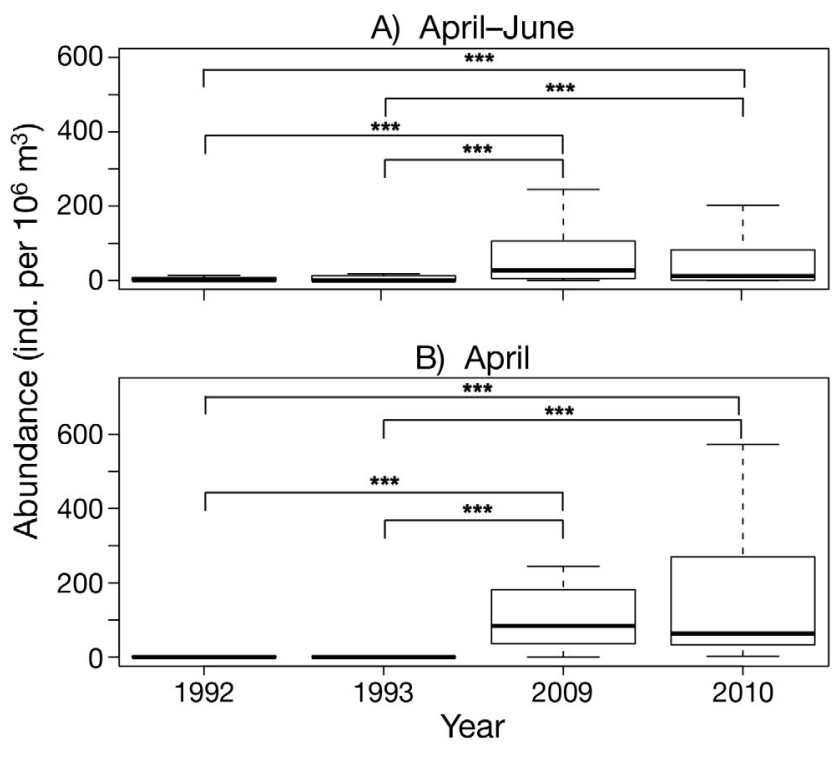

Fig. 2. Alosa fallax. Median abundances of adult twaite shad in the Elbe estuary for (A) April to June and (B) April only in 1992, 1993, 2009 and 2010. The horizontal lines inside the boxes mark the median, the borders of the boxes the first and third quartiles and the whiskers the most extreme data points that lie within 1.5 times the interquartile range. For clarity, outliers are omitted. Pairwise Mann-Whitney comparisons: ${ }^{* *} \mathrm{p}<0.001$

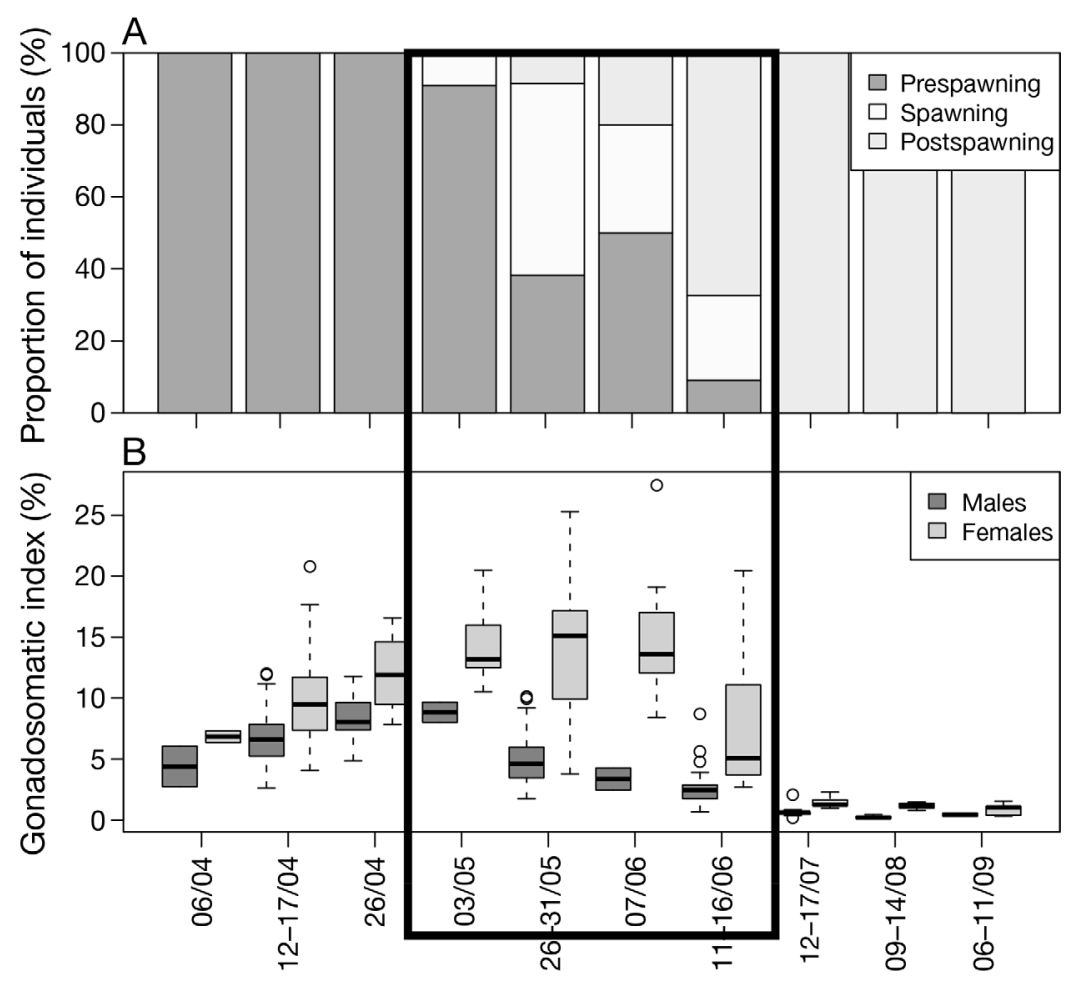

Fig. 3. Alosa fallax. (A) Maturity (proportion of individuals in the prespawning, spawning and postspawning groups) and (B) average gonadosomatic index of adult twaite shad sampled in 2010 (dates shown as dd/mm). The bold rectangle denotes the spawning period. See Fig. 2 for explanation of boxplots 
validation was not possible because of the very small sample size $(\mathrm{N}=2)$. For females, the average GSI was maximal on 26-31 May and decreased significantly until 11-16 June $(U=372, \mathrm{df}=1, \mathrm{p}<0.01, \mathrm{~N}=49$; Fig. 3B).

Thus, in 2010, the spawning period occurred from at least 3 May to 16 June. As no data exist between sampling dates, the spawning period could have started as early as 27 April and could have lasted until 11 July at the latest.

In 2010, abundances differed significantly between the months $(H=142.9, \mathrm{df}=5, \mathrm{p}<0.001, \mathrm{~N}=264)$. They illustrated an upstream movement of the spawning stock in April and May, which was followed by a downstream movement from June to September (Fig. 4). High abundances occurred in April and May; however, abundances in May were significantly higher than in any other month in 2010 ( $U=$
537.5-1900.5, df = 1, $\mathrm{p}<0.001, \mathrm{~N}=88$ for 5 pairwise comparisons).

\section{Spawning area}

In the lower estuary, a high proportion of prespawning and postspawning individuals occurred in 2010 (Fig. 5). The proportion of spawning individuals differed significantly between the subareas of the estuary $\left(\chi^{2}=116.539, \mathrm{df}=2, \mathrm{p}<0.001, \mathrm{~N}=642\right)$. A higher proportion of spawning individuals was observed in the middle ( $\mathrm{p}<0.001, \mathrm{~N}=557)$ and upper estuary ( $\mathrm{p}<0.001, \mathrm{~N}=473$ ) compared with the lower estuary. These results are supported by an incidental observation of a spawning event at the most downstream station in the upper estuary during sampling in May 2010.
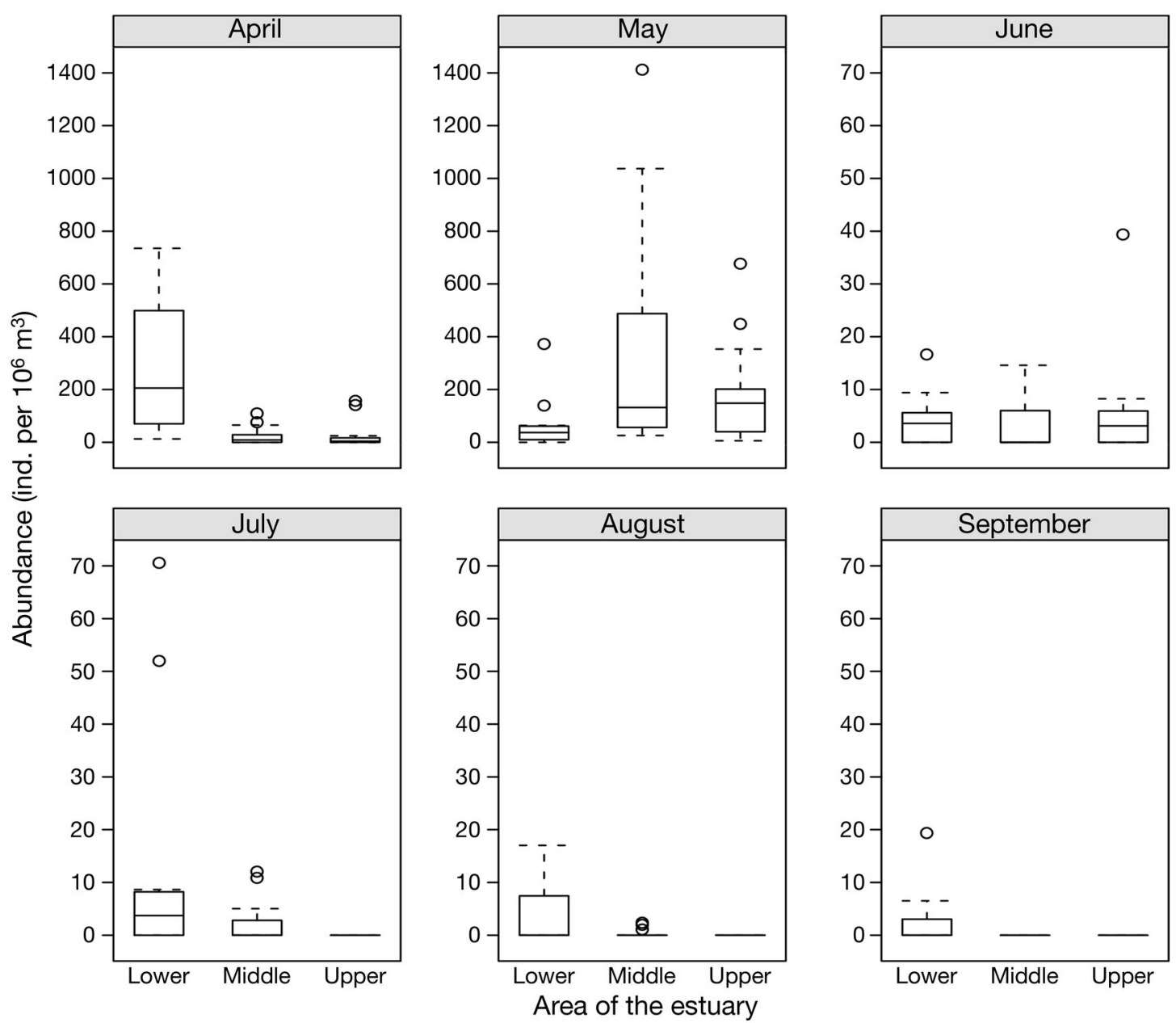

Fig. 4. Alosa fallax. Twaite shad abundances during each month and in each subarea of the Elbe estuary in 2010. See Fig. 2 for explanation of boxplots 


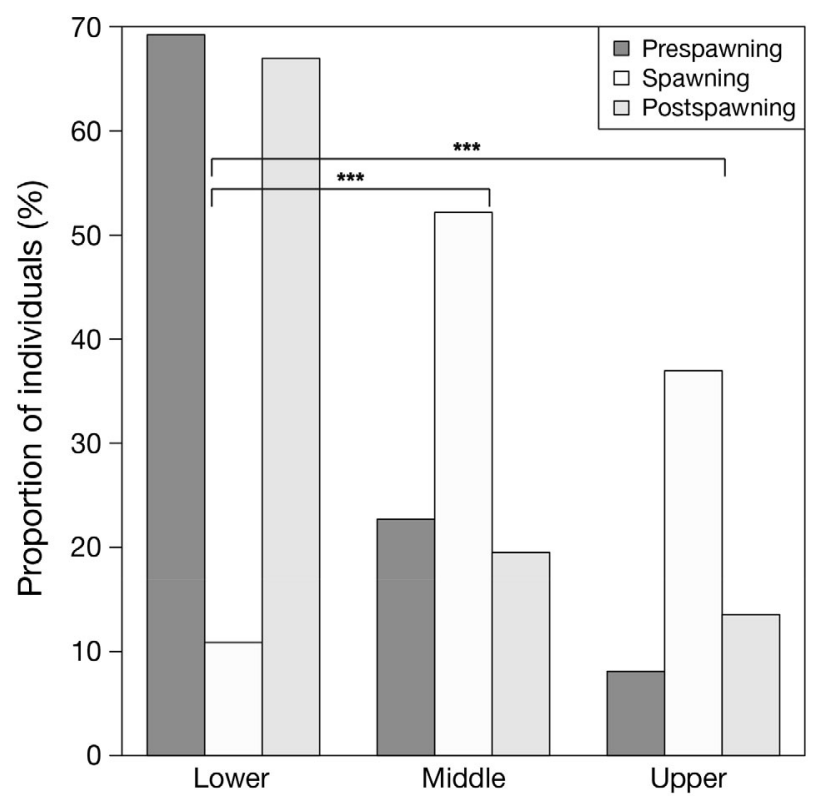

Fig. 5. Alosa fallax. Proportion of different maturity stages of twaite shad in the 3 subareas of the Elbe estuary in 2010. ${ }^{* * *} \mathrm{p}<0.001$

Twaite shad abundances combined for May and June 2010 did not differ among the 3 subareas $(H=$ 1.3, df $=2, \mathrm{p}>0.5, \mathrm{~N}=88$, Fig. 4). However, considering May abundances only, which were much higher than in June, significant differences were observed between the subareas $(H=8.7, \mathrm{df}=2, \mathrm{p}<$ $0.05, \mathrm{~N}=44)$. Twaite shad exhibited higher abundances in the middle than in the lower estuary $(U=$ 35.0, $\mathrm{df}=1, \mathrm{p}<0.01, \mathrm{~N}=28$ ).

\section{Environmental parameters}

In 2010, during the spawning period from May to June, water temperature was $17.6 \pm 2.1^{\circ} \mathrm{C}$ in the lower, $18.6 \pm 1.9^{\circ} \mathrm{C}$ in the middle and $19.4 \pm 1.7^{\circ} \mathrm{C}$ in the upper estuary. The corresponding oxygen concentrations were $7.8 \pm 0.6,7.0 \pm 1.0$ and $7.5 \pm 0.9 \mathrm{mg}$ $\mathrm{l}^{-1}$, respectively. Salinity was highest in the lower estuary $(3.0 \pm 3.3)$ and ranged from $0.5 \pm 0.1$ to $0.4 \pm$ 0 in the middle and upper estuary, respectively.

In 1992-1993 and 2009-2010, water temperature increased from April to June. In 1992 and 1993, mean April water temperatures were $10.6 \pm 0.8^{\circ} \mathrm{C}$ and $8.3 \pm$ $0.5^{\circ} \mathrm{C}$, respectively. In the $2000 \mathrm{~s}$, mean April water temperatures of $13.6 \pm 6.5^{\circ} \mathrm{C}$ and $11.5 \pm 1.5^{\circ} \mathrm{C}$ were measured for 2009 and 2010. Clear differences in the April water temperature were determined between the decades $(H=74.8, \mathrm{df}=3, \mathrm{p}<0.001, \mathrm{~N}=109)$, with higher mean temperatures in 2009 and 2010. This was statistically significant for the comparisons between 1992 and 2009, 1993 and 2009 as well as 1993 and $2010(U=0-4.5, \mathrm{df}=1, \mathrm{p}<0.001, \mathrm{~N}=53-56$ for 3 pairwise comparisons). In May, mean water temperatures were $17.1 \pm 1.4^{\circ} \mathrm{C}$ for $1993,14.9 \pm 0.5^{\circ} \mathrm{C}$ for 2009 and $16.8 \pm 0.9^{\circ} \mathrm{C}$ for 2010 . No abiotic data were available for May 1992 because of damage to the multi probe during this survey. There were significant differences between the decades $(H=$ 64.0, $\mathrm{df}=2, \mathrm{p}<0.001, \mathrm{~N}=98$ ): water temperature was significantly higher in 1993 than in 2009 ( $U=427.5$, $\mathrm{df}=1, \mathrm{p}<0.001, \mathrm{~N}=54$ ). In June, mean water temperatures of $19.9 \pm 0.7^{\circ} \mathrm{C}$ and $18.2 \pm 1.0^{\circ} \mathrm{C}$ occurred in 1992 and 1993, respectively. In June 2009 and 2010 , mean water temperatures were $16.6 \pm 0.4^{\circ} \mathrm{C}$ and $20.4 \pm 0.7^{\circ} \mathrm{C}$, respectively. Differences existed between the years $(H=64.0, \mathrm{df}=2, \mathrm{p}<0.001, \mathrm{~N}=98$ and $U=82.8, \mathrm{df}=3, \mathrm{p}<0.001, \mathrm{~N}=106$, respectively), but no clear trend was obvious between the decades. While in 2009, June water temperatures were significantly lower than in 1992 and 1993 ( $U=344.0-$ 352.0, $\mathrm{df}=1, \mathrm{p}<0.001, \mathrm{~N}=42-54$ for 2 pairwise comparisons), water temperature in June 2010 was significantly higher than in $1993(U=11.5, \mathrm{df}=1, \mathrm{p}<$ 0.001, $\mathrm{N}=54$ ).

Oxygen concentrations in the Elbe estuary ranged from 4.5 to $13.7 \mathrm{mg} \mathrm{l}^{-1}$ between April and June in 1992, 1993, 2009 and 2010. The lowest mean concentrations in 1992, 2009 and 2010 were found in June $\left(7.4 \pm 1.2,7.9 \pm 1.6\right.$ and $7.3 \pm 0.8 \mathrm{mg} \mathrm{l}^{-1}$, respectively). In 1993, the lowest mean oxygen concentration occurred in May $\left(6.2 \pm 1.4 \mathrm{mg} \mathrm{l}^{-1}\right)$. Oxygen concentrations never reached critical values $<4 \mathrm{mg} \mathrm{l}^{-1}$ during the research surveys from April to June either in the 1990s or in 2009-2010.

In all 4 years considered, mean salinities were highest in the lower estuary, with values of $3.6 \pm 3.3$ in $1992,10.0 \pm 6.6$ in $1993,5.3 \pm 5.1$ in 2009 and $2.7 \pm$ 3.1 in 2010 for the combined months of April to June. In the middle estuary, mean salinities were $0.6 \pm 0.7$ in $1992,0.9 \pm 0.7$ in 1993, $0.4 \pm 0.2$ in 2009 and $0.4 \pm$ 0.1 in 2010. The upper estuary was characterised by the lowest values: $0.5 \pm 0.2$ in $1992,0.4 \pm 0.1$ in 1993, $0.3 \pm 0.1$ in 2009 and $0.4 \pm 0$ in 2010. Between the decades, salinities only differed in the middle estuary from May to June $(H=19.0-27.6, \mathrm{df}=2-3, \mathrm{p}<0.001$, $\mathrm{N}=36-42)$ and in the upper estuary from April to June $(H=13.2-31.0, \mathrm{df}=2-3, \mathrm{p}<0.001, \mathrm{~N}=34-40)$. In May and June 2009 and 2010, salinities in the middle estuary were significantly lower than in May and June 1992 and $1993(U=57.0-96.0, \mathrm{df}=1, \mathrm{p}<$ 0.01-0.001, $\mathrm{N}=20-22$ for 6 pairwise comparisons). 
From April to June 2009, salinities in the upper estuary were also lower than in 1992 and $1993(U=$ 32.0-63.5, df $=1, \mathrm{p}<0.01-0.001, \mathrm{~N}=18-20$ ). From April to June 2010, a trend of lower mean salinities in comparison to 1992 and 1993 was obvious; however, this was only statistically significant for June 1992 $(U=32, \mathrm{df}=1, \mathrm{p}<0.01, \mathrm{~N}=18)$.

\section{DISCUSSION}

In this study, information on gonad maturity and GSI served as an indicator of the spawning time and spawning area of twaite shad in the Elbe estuary. GSI is a well-accepted index with which to identify the spawning time of fishes (King 1995), and a good agreement with maturity stages in this study indicates that both methods are valuable for this purpose. In the same manner, GSI and maturity stage were used to locate the spawning area of twaite shad. Surveys of early life stages could also have been used, even though both methods have disadvantages. Early life stages can float away on the current (Hass 1968) so that the catch location of eggs or early larvae does not necessarily represent the place of spawning. Using gonad maturity and/or GSI, the daily movements of spawners are not known, and similarly, the catch locations may not be identical to the locations of spawning. However, females migrate to the spawning grounds only if they are close to spawning and move back into the sea shortly after spawning (Hass 1965, Maitland \& Lyle 2005). In contrast, males arrive early at the spawning grounds and stay there during the spawning season (Hass 1965, Maitland \& Lyle 2005). Both behaviours indicate that the spawning maturity stage and a high GSI only occurred when individuals were in the vicinity of the spawning grounds, which supports the usefulness of this method. To allow for slight differences between the catch station and the real spawning ground, a relatively coarse spatial resolution was chosen in terms of the 3 subareas. This also facilitated the comparison with other studies that relied on different methods, e.g. early life stage surveys.

This study demonstrated that the twaite shad Alosa fallax spawning stock of the Elbe estuary has increased significantly in numbers over the past years, with median abundances of 27.3 and 11.9 in 2009 and 2010 in comparison to median values of 0.9 and 0 in 1992 and 1993. A comparison of abundance data from the 1980s and the 1990s has not revealed an increasing population so far (Thiel et al. 1996). Thus, recovery started recently. The recovery was apparent, even though anthropogenic impacts at the turn of the millennium resulted in recurrent oxygen deficiencies in the Elbe estuary between June and August (FGG Elbe 2007, Kerner 2007). As the spawning activity in the estuary lasted at least from early May to mid-June, late spawners could be constrained during their migration by poor oxygen conditions, as observed in the river Scheldt for the entire stock (Maes et al. 2007). However, oxygen concentrations measured during the main freshwater phase from April to June did not point to harmful values within the years observed. Apart from that, high abundances in April and May indicated that only a small proportion of the spawning stock may have been affected in June.

Accordingly, there must have been other factors besides the oxygen concentration that favoured the positive development of the Elbe spawning stock of Alosa fallax. A stock-recruitment model for the river Severn population in the UK predicted a considerable increase in numbers of individuals if the mean water temperature rises as a consequence of climate change (Aprahamian et al. 2010). As twaite shad is a Lusitanian species, which has its main distribution in the Iberian region, this development may especially apply to populations of the northern distribution limit (Aprahamian et al. 2010). Indeed, over the last 5 decades, a long-term water temperature increase has been observed in the North Sea (e.g. Radach et al. 1990, Marsh \& Kent 2006, Sherman et al. 2007). Since the 1990s, positive water temperature anomalies have been measured regularly in the German Bight (Hughes et al. 2011), the region of the southern North Sea close to the mouth of the Elbe estuary, and severe winters with ice floes in the Wadden Sea are increasingly absent (Colijn \& Fanger 2011). Similar temperature increases may apply to the adjacent Elbe estuary as well, which is in line with the observed earlier spring temperature rise.

The onset of spawning is highly dependent on water temperature (Aprahamian et al. 2003). The spawning period identified in this study was in accordance with the fact that northern stocks spawn later in the year than southern stocks (Aprahamian et al. 2003). The time of spawning was similar to that of the populations in the Seine, France, and the Solway Firth, Scotland, which presumably spawn in June (Roule 1922, Maitland \& Lyle 2005). With regard to climate change, a long-term water temperature increase should also result in an earlier onset of the freshwater phase (Aprahamian et al. 2010), and thus an earlier spawning period of twaite shad. In the 
early 1960s, the spawning period of twaite shad in the Elbe estuary usually lasted from early May to mid-June, but was delayed in colder years (Hass 1968). In 2010, spawning individuals occurred within the same period, thus a trend of an earlier onset of spawning could not be identified in this year. However, the most considerable abundance increases between the decades occurred at the onset of the spawning migration (Fig. 2B), which may be associated with the higher mean water temperatures observed in April 2009 and 2010. This indicated that at the onset of the freshwater phase a huge part of the spawning stock immigrated within a shorter time period, i.e. in a more compact form than in the 1990s, when April abundances were low. This may be another consequence of climate change.

In the early 1990s, an upstream shift of the spawning grounds of Alosa fallax in the Elbe estuary was probably the result of improvements in water quality (Thiel et al. 1996). The present extension of the spawning area incorporates the prior range, which occurred mainly between rkm 645 and 660 at the beginning of the 1990s (Thiel et al. 1996) and between rkm 635 and 660 at the end of the 1990s (Gerkens \& Thiel 2001). However, the present lower border of the spawning area extends further downstream to rkm 675. Higher mean abundances and higher numbers of spawning individuals suggest that, within this range, the main spawning area might be located within the middle part of the estuary (rkm 660-675) and therefore further downstream than before. For various European river systems such as the rivers Ebro, Scheldt and Severn, twaite shad is known to spawn exclusively in freshwater (Maitland \& Lyle 2005, Maes et al. 2008, López et al. 2011). The same is true for the congeners American shad in the Hudson River in New York and major rivers in Virginia (Massmann 1952, Limburg 2001) and blueback herring in the Connecticut and Thames rivers in Connecticut (Loesch \& Lund 1977). Thus the reduced salinity in the middle and upper Elbe estuary in comparison to conditions during the 1990s could have extended the area of suitable spawning habitat. This could have further benefited the twaite shad population. However, the spawning area in the Elbe estuary was located in both freshwater and areas of low salinities $(0.5 \pm 0.1)$, which is an exceptional finding.

This study provides clear evidence for the recovery of the twaite shad spawning stock in the Elbe estuary, based on abundance data. This new information on a large North Sea estuary, together with indications of increasing numbers of twaite shad in the Wadden Sea, German coastal areas and the Weser
(Stelzenmüller et al. 2004, Neudecker \& Damm 2005, Thiel \& Backhausen 2006), points to a general recovery of twaite shad in the North Sea. However, it cannot be excluded that a large proportion of twaite shad individuals in the southern North Sea area stems from only a single stock, namely from the Elbe estuary. Nevertheless, the findings on the recovery of the Elbe stock of twaite shad are in line with formerly published Alosa fallax recoveries in the Baltic Sea (Thiel et al. 2008) and in the Mediterranean (López et al. 2007). As a result of these prior findings, the IUCN Red List listed twaite shad as a species of Least Concern (Freyhof \& Kottelat 2008), and in Lithuania twaite shad was removed from the national red list in 2005 (Zolubas \& Piščikas 2007). However, some red lists still regard twaite shad as an endangered species in the Baltic and in German waters of the North Sea (Fricke et al. 1994, HELCOM 2007). Considering the prior and present findings, the current vulnerability status of $A$. fallax in these regions should be reevaluated. However, as seen with twaite shad in the southern Baltic Sea (Thiel et al. 2008), strong fluctuations in populations can occur. Hence, twaite shad spawning stocks should be monitored continuously to track their development and to ensure their maintenance.

Acknowledgements. Thanks to Dennis Eick, Renate Thiel and 3 reviewers for their constructive criticism and recommendations on earlier versions of the manuscript. The Federal Waterways Engineering and Research Institute (BAW) kindly provided the map for the Elbe estuary. This study was financially supported by the Estuary and Wetland Research Graduate School Hamburg (ESTRADE) as a member of the State Excellence Initiative (LEXI) funded by the Hamburg Science and Research Foundation. Data sampling was funded by the Federal Ministry of Education and Research, within the project KLIMZUG-NORD.

\section{LITERATURE CITED}

Aprahamian MW, Aprahamian CD (1990) Status of the genus Alosa in the British Isles; past and present. J Fish Biol 37:257-258

Aprahamian MW, Baglinière $J$, Sabatié MR, Alexandrino $P$, Thiel R, Aprahamian CD (2003) Biology, status, and conservation of the anadromous Atlantic twaite shad Alosa fallax fallax. Am Fish Soc Symp 35:103-124

Aprahamian MW, Aprahamian CD, Knights AM (2010) Climate change and the green energy paradox: the consequences for twaite shad Alosa fallax from the River Severn, UK. J Fish Biol 77:1912-1930

Arge Elbe (2005) EG-Wasserrahmenrichtlinie: Konzept zur Überwachung des Zustands der Gewässer-Bearbeitungsgebiet Tideelbestrom - (C-Ebene). Draft. Sonderaufgabenbereich Tideelbe der Arge Elbe der Länder Hamburg - Niedersachsen-Schleswig-Holstein mit Wassergütestelle Elbe. Landesamt für Natur und Umwelt 
des Landes Schleswig-Holstein, Flintbek. Available at www.fgg-elbe.de/einzugsgebiet/kortel.html?file=tl_files/ Download-Archive/TEL/allgemeines/Konz_Moni_TEL Strom.pdf (accessed 21 Nov 2012)

Berg S (1998) 7.15 Ferskvandsfisk. In: Stoltze M, Pihl S (eds) Rødliste 1997 over planter og dyr i Danmark. Skov- og Naturstyrelsen, Copenhagen, p 165-169

Bervoets L, Coeck J, Verheyen RF (1990) The value of lowland rivers for the conservation of rare fish in Flanders. J Fish Biol 37:223-224

Colijn F, Fanger H (2011) Klimabedingte Änderungen in aquatischen Ökosystemen: Elbe, Wattenmeer und Nordsee. In: von Storch $\mathrm{H}$, Claussen M (eds) Klimabericht für die Metropolregion Hamburg. Springer, Berlin, p 177-194

Costello M, Elliott M, Thiel R (2002) Endangered and rare species. In: Elliott M, Hemingway KL (eds) Fishes in estuaries. Blackwell Science, Oxford, p 217-265

Ehrenbaum E (1894) Beiträge zur Naturgeschichte einiger Elbfische. In: Kommission zur wissenschaftlichen Untersuchung der deutschen Meere in Kiel, Biologische Anstalt auf Helgoland (eds) Wissenschaftliche Meeresuntersuchungen, 1. Verlag von Lipsius \& Tischer, Kiel, p 35-82

FGG Elbe (2007) Sauerstoffgehalte der Tide-Elbe. Wassergütestelle Elbe, Hamburg. Available at www.fgg-elbe.de/ dokumente/fachberichte.html (accessed 26 March 2012)

Freyhof J, Kottelat M (2008) Alosa fallax. IUCN Red List of Threatened Species. Available at www.iucnredlist.org (accessed 27 July 2012)

Fricke R, Berghahn R, Rechlin O, Neudecker T, Winkler H, Bast H, Hahlbeck E (1994) Rote Liste und Artenverzeichnis der Rundmäuler und Fische (Cyclostomata \& Pisces) im Bereich der deutschen Nord- und Ostsee. In: Nowak E, Blab J, Bless R (eds) Rote Liste der gefährdeten Wirbeltiere in Deutschland, Vol. 42. Kilda Verlag, Greven, p 157-176

Gerkens M, Thiel R (2001) Habitat use of age-0 twaite shad (Alosa fallax Lacépède, 1803) in the tidal freshwater region of the Elbe River, Germany. Bull Fr Peche Piscicult 362/363:773-784

Hass H (1965) Untersuchungen über den Laichfischbestand der Elbfinte, Alosa fallax (Lacépède 1803). Arch FischWiss 16:150-168

Hass H (1968) Untersuchungen über die vertikale und horizontale Verteilung der Eier der Finte, Alosa fallax (Lacépède 1803), in der Elbe. Arch FischWiss 19:46-55

HELCOM (Helsinki Commission) (2007) HELCOM Red List of threatened and declining species of lampreys and fishes of the Baltic Sea. Baltic Sea Environment Proceedings No. 109. Available at www.helcom.fi/stc/files/ Publications/Proceedings/bsep109.pdf (accessed 27 July 2012)

Hughes SL, Holliday NP, Beszczynska-Möller A (2011) ICES Report on Ocean Climate 2010. ICES Cooperative Research Report No. 309, International Council for the Exploration of the Sea, Copenhagen

Jager Z, Bolle L, Dänhardt A, Diederichs B, Neudecker T, Scholle J, Vorberg R (2009) Fish. Thematic Report No. 14. In: Marencic H, Vlas J de (eds) Quality status report 2009, Vol. 25. Trilateral Monitoring and Assessment Group, Common Wadden Sea Secretariat, Wilhelmshaven, p 1-41

Kerner M (2007) Effects of deepening the Elbe Estuary on sediment regime and water quality. Estuar Coast Mar Sci 75:492-500
King MG (1995) Fisheries biology, assessment and management. Fishing News Books, Blackwell Science, Oxford

> King JJ, Roche WK (2008) Aspects of anadromous allis shad (Alosa alosa Linnaeus) and twaite shad (Alosa fallax Lacépède) biology in four Irish Special Areas of Conservation (SACs): status, spawning indications and implications for conservation designation. Hydrobiologia 602: $145-154$

Klinkhardt M (1996) Der Hering. Westarp-Wissenschaften, Magdeburg

Kühl H (1976) Zum Stand der Hamenfischerei in der Unterelbe. N Arch f Nds 25:315-324

Limburg KE (2001) Through the gauntlet again: demographic reconstructing of American shad by migration. Ecol Lett 82:1584-1596

Loesch JG, Lund WA (1977) A contribution to the life history of the blueback herring, Alosa aestivalis. Trans Am Fish Soc 106:583-589

> López MA, Gázquez N, Olmo-Vidal JM, Aprahamian MW, Gisbert E (2007) The presence of anadromous twaite shad (Alosa fallax) in the Ebro River (western Mediterranean, Spain): an indicator of the population's recovery? J Appl Ichthyol 23:163-166

López MA, Andrée KB, Sánchez R, Queral JM, Franch N, Schneider P, Gisbert E (2011) First characterization of the spawning habitat and mating behaviour of twaite shad in the Ebro River (Western Mediterranean). J Appl Ichthyol 27:53-55

Maes J, Stevens M, Ollevier F (2005) The composition and community structure of the ichthyofauna of the upper Scheldt estuary: synthesis of a 10-year data collection (1991-2001). J Appl Ichthyol 21:86-93

Maes J, Stevens M, Breine J (2007) Modelling the migration opportunities of diadromous fish species along a gradient of dissolved oxygen concentration in a European tidal watershed. Estuar Coast Mar Sci 75:151-162

> Maes J, Stevens M, Breine J (2008) Poor water quality constrains the distribution and movements of twaite shad Alosa fallax fallax (Lacépède, 1803) in the watershed of river Scheldt. Hydrobiologia 602:129-143

Maitland PS, Hatton-Ellis TW (2003) Ecology of the allis and twaite shad. Conserving Natura 2000 Rivers Ecology Series No. 3. English Nature, Peterborough

> Maitland PS, Lyle AA (2005) Ecology of allis shad Alosa alosa and twaite shad Alosa fallax in the Solway Firth, Scotland. Hydrobiologia 534:205-221

Maksimov J (2004) The 'revival' of the twaite shad (Alosa fallax, Lacépède 1803) population in the Curonian Lagoon. Bull Sea Fish Inst 161:61-62

Marsh R, Kent E (2006) Impacts of climate change on sea surface temperature. Marine Climate Change Impacts. Annual Report Card 2006: Summary Report. MCCIP, Lowesoft. Available at www.mccip.org.uk/annual-reportcard/2006.aspx (accessed 18 July 2012)

> Massmann WH (1952) Characteristics of spawning areas of shad, Alosa sapidissima (Wilson) in some Virginia streams. Trans Am Fish Soc 81:78-93

Möller H, Dieckwisch B (1991) Larval fish production in the tidal River Elbe 1985-1986. J Fish Biol 38:829-838

> Möller H, Scholz U (1991) Avoidance of oxygen-poor zones by fish in the Elbe River. J Appl Ichthyol 7:176-182

Neudecker T, Damm U (2005) Maifische an der deutschen Nordseeküste-zum Auftreten von Finte (Alosa fallax) und Alse (Alosa alosa). Inf Fischforsch 52:43-50 
Pihl L, Cattrijsse A, Codling I, Mathieson S, McLusky DS, Roberts C (2002) Habitat use by fishes in estuaries and other brackish areas. In: Elliott M, Hemingway KL (eds) Fishes in estuaries. Blackwell Science, Oxford, p 10-53

R Development Core Team (2011) R: A language and environment for statistical computing. R Foundation for Statistical Computing, Vienna

Radach G, Berg J, Hagmeier E (1990) Long-term changes of the annual cycles of meteorological, hydrographic, nutrient and phytoplankton time series at Helgoland and at LV ELBE 1 in the German Bight. Cont Shelf Res 10: 305-328

Repečka R (2003) Changes in biological indices and abundance of salmon, sea trout, smelt, vimba and twaite shad in the coastal zone of the Baltic Sea and the Curonian Lagoon at the beginning of spawning migration. Acta Zool Lituanica 13:195-216

Roule L (1922) La migration reproductrice et la protandrie de l'alose feinte (Alosa finta L.). Ann Sci Nat Zool 5: $61-77$

Sabatié R, Baglinière JL (2001) Quelques traits bioécologiques des aloses du Maroc; un patrimoine culturel et socio-économique récemment disparu. Bull Fr Peche Piscic 362/363:903-917

Scholle J, Schuchardt B (2012) A fish-based index of biotic integrity - FAT-TW an assessment tool for transitional waters of the northern German tidal estuaries. Coastline Rep 18:1-73

Sherman K, Belkin I, O'Reiilly J (2007) Variability of large marine ecosystems in response to global change. CM Documents. ICES, Copenhagen. Available at www.vliz. be/imisdocs/publications/226406 (accessed 18 July 2012)

Stelzenmüller V, Maynou F, Ehrich S, Zauke G (2004) Spatial analysis of twaite shad Alosa fallax (Lacepède, 1803), in the southern North Sea: application of non-linear geostatistics as a tool to search for Special Areas of Conservation. Int Rev Hydrobiol 89:337-351

Sterner E (1918) Die niederelbische Küstenfischerei. II. Die

Editorial responsibility: Cornelius Hammer,

Rostock, Germany
Fischereiarten. 5. Der Maifischfang. Fischerbote 10: 13-16

Taverny C, Elie P (2001) Répartition spatio-temporelle de la grande alose Alosa alosa (Linné, 1766) et de l'alose feinte Alosa fallax (Lacépède, 1803) dans le Golfe de Gascogne. Bull Fr Peche Piscic 362/363:803-821

Thiel R (2003) Ästuare - wichtige Lebensräume für Fische der Nord- und Ostsee. Meer Mus 17:36-44

Thiel R (2009) Das Ökosystem der Niederelbe - Fauna und Flora unter dem Einfluss menschlicher Aktivitäten. Nat Wiss 5:12-14

Thiel R, Backhausen I (2006) Survey of Natura 2000 Fish Species in the German North and Baltic Seas. In: von Nordheim H, Boedeker D, Krause JC (eds) Progress in marine conservation in Europe. Springer, Berlin, p 157-178

Thiel R, Potter IC (2001) The ichthyofaunal composition of the Elbe estuary: an analysis in space and time. Mar Biol 138:603-616

> Thiel R, Sepulveda A, Kafemann R, Nellen W (1995) Environmental factors as forces structuring the fish community of the Elbe estuary. J Fish Biol 46:47-69

Thiel R, Sepulveda A, Oesmann S (1996) Occurrence and distribution of twaite shad (Alosa fallax Lacépède) in the lower Elbe River, Germany. In: Kirchhofer A, Hefti D (eds) Conservation of endangered freshwater fish in Europe. Birkhäuser Verlag, Basel, p 157-170

> Thiel R, Riel P, Neumann R, Winkler HM, Böttcher U, Gröhsler T (2008) Return of twaite shad Alosa fallax (Lacépède, 1803) to the southern Baltic Sea and the transitional area between the Baltic and North Seas. Hydrobiologia 602:161-177

Turan C, Basusta N (2001) Comparison of morphometric characters of twaite shad (Alosa fallax nilotica, Geoffroy Saint-Hilaire, 1808) among three areas in Turkish seas. Bull Fr Peche Piscic 362/363:1027-1035

Zolubas T, Piščikas V (2007) Twaite shad (Alosa fallax (Lacépède)) migrations and population state chronology. Žuvininkystè Lietuvoje 7:76-88

Submitted: August 8, 2012; Accepted: December 14, 2012 Proofs received from author(s): February 25, 2013 